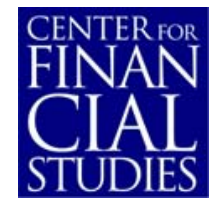

No. $2009 / 22$

Did Fair-Value Accounting Contribute to the Financial Crisis?

Christian Laux and Christian Leuz 


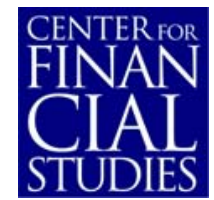

\section{Center for Financial Studies}

The Center for Financial Studies is a nonprofit research organization, supported by an association of more than 120 banks, insurance companies, industrial corporations and public institutions. Established in 1968 and closely affiliated with the University of Frankfurt, it provides a strong link between the financial community and academia.

The CFS Working Paper Series presents the result of scientific research on selected topics in the field of money, banking and finance. The authors were either participants in the Center's Research Fellow Program or members of one of the Center's Research Projects.

If you would like to know more about the Center for Financial Studies, please let us know of your interest.
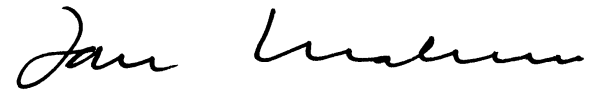

Prof. Dr. Jan Pieter Krahnen 


\title{
Did Fair-Value Accounting Contribute to the Financial Crisis?
}

\author{
Christian Laux ${ }^{1}$ and Christian Leuz ${ }^{2}$
}

\section{October 2009}

\begin{abstract}
:
The recent financial crisis has led to a major debate about fair-value accounting. Many critics have argued that fair-value accounting, often also called mark-to-market accounting, has significantly contributed to the financial crisis or, at least, exacerbated its severity. In this paper, we assess these arguments and examine the role of fair-value accounting in the financial crisis using descriptive data and empirical evidence. Based on our analysis, it is unlikely that fair-value accounting added to the severity of the current financial crisis in a major way. While there may have been downward spirals or asset-fire sales in certain markets, we find little evidence that these effects are the result of fair-value accounting. We also find little support for claims that fair-value accounting leads to excessive write-downs of banks' assets. If anything, empirical evidence to date points in the opposite direction, that is, towards overvaluation of bank assets.
\end{abstract}

JEL-Classifications: G14, G15, G30, K22, M41, M42

Key Words: Mark-to-Market Accounting, Financial Institutions, Liquidity, Financial Crisis, Banks, Financial Regulation, Procyclicality, Contagion. 
In its pure form, fair-value accounting involves reporting assets and liabilities on the balance sheet at fair value and recognizing changes in fair value as gains and losses in the income statement. When market prices are used to determine fair value, fair-value accounting is also called mark-to-market accounting. Critics argue that fair-value accounting has exacerbated the severity of the 2008 financial crisis. In this paper, we evaluate the merits of this claim.

The main allegations are that fair-value accounting contributes to excessive leverage in boom periods and leads to excessive write-downs in busts. The write-downs deplete bank capital and can set off a downward spiral, as banks are forced to sell assets at "fire sale" prices, which in turn can lead to contagion as prices from asset-fire sales become relevant for other banks. ${ }^{1}$ In much of the debate, these arguments are taken for granted and specific evidence of how fair-value accounting has created problems during the crisis is rarely provided.

We discuss these arguments and examine descriptive and empirical evidence that sheds light on the role of fair-value accounting in the crisis. While it is clear that large losses can cause problems for banks, the relevant question for our article is whether reporting these losses under fair-value accounting creates additional problems. Similarly, it is clear that determining fair values for illiquid assets in a crisis is difficult, but did reporting fair values of illiquid assets make matters worse? Would the market have reacted differently if banks had not reported their losses or used a different set of accounting rules, for instance, historical-cost accounting? If not, it is difficult to argue that fair-value accounting per se contributed to the crisis.

\footnotetext{
For summaries of the pros and cons of fair-value accounting and further references, we refer readers to Landsman (2007), Penman (2007), Benston (2008), Ryan (2008), SEC (2008a) and Laux and Leuz (2009). For discussions of fair-value accounting and its procyclical effects, ECB (2004), Banque de France (2008) and IMF (2008) are useful starting points. For accounts arguing that fair-value accounting played a substantial role in deepening the financial crisis, see American Bankers Association (2008), Wallison (2008a, 2008b), Whalen (2008), and Forbes (2009). For accounts defending fair-value accounting during the crisis, see Ball (2008), Turner (2008), and Veron (2008).
} 
Furthermore, downward spirals can arise because contracts (e.g., margin and collateral requirements, haircuts) are based on market values or because banks use market values to manage their business (e.g., Value at Risk techniques). It is easy to confuse problems that stem from using market prices in private arrangements with problems from using market values in accounting. Thus, it is important to be specific about the links through which write-downs under fair-value accounting can create problems, be it capital regulation, contracts, a fixation on accounting numbers by managers or investors, or inefficient markets.

We begin our analysis by explaining in more detail how pure mark-to-market accounting can cause problems in a crisis. We then outline extant accounting rules for banks' key assets. It is important to recognize that fair-value accounting as stipulated by the accounting rules is different from pure mark-to-market accounting. Extant rules allow banks to deviate from market prices under certain circumstances. Moreover, not all fair value changes enter the computation of banks' regulatory capital. These provisions should act as safeguards, making downward spirals and contagion less likely to occur as compared to pure mark-to-market accounting.

After this background information on how fair-value accounting actually works, we examine possible mechanisms through which fair-value accounting could have contributed to the financial crisis. We consider several questions: Did fair-value accounting contribute to the problems of investment funds that invested in mortgage-backed securities, and thus contributed to the demise of financial institutions like investment banks that issued those funds? Did fair-value accounting weaken bank holding companies or investment banks in other ways? Is there evidence that banks made use of the safeguards and discretion in fair-value accounting rules and deviated from potentially distorted market prices? Is there evidence that fair-value accounting led to excessive write-downs of financial assets? 
Based on our analysis and the available evidence, it is unlikely that fair-value accounting added to the severity of the financial crisis. The crisis started when housing prices declined and delinquency and default rates increased. Uncertainty and information asymmetry dried up the refinancing and repo markets, which were crucial for investment funds, investment banks, and several large bank holding companies. Clearly, these events and the severe illiquidity of many markets posed serious challenges in determining fair values of financial assets. But while there likely have been downward spirals and asset-fire sales, there is little evidence that spirals or fire sales occurred as a direct result of fair-value accounting or that fair-value accounting led to widespread contagion.

The business model of investment funds and investment banks is based on market values and hence fair-value accounting is not an option, it is a necessity. More importantly, investors would have been concerned about investment banks (or funds) with substantial (subprime) mortgage exposure, even if they had not written down mortgage-related assets and simply reported them at historical cost. We therefore have little reason to believe that problems would have been less severe under historical cost accounting, which is generally viewed as the primary alternative to fair-value accounting. If anything, less transparency would have made matters worse.

For bank holding companies, the concerns about fair-value accounting have more merit because they do not rely on investors' (or managers') reactions to the disclosure of fair-value information, but instead can be based on the use of accounting numbers for regulatory capital requirements. But even considering this link, it is unlikely that fair-value accounting exaggerated banks' problems in the crisis. First, the impact of fair value changes on bank income and regulatory capital is much more limited than often claimed, perhaps with the exception of a few banks with large trading positions. Second, we provide evidence that bank holding companies (as 
well as investment banks) made ample use of the safeguards and discretion built into fair-value accounting. For instance, many banks with substantial real-estate exposure and large trading portfolios used cash-flow-based models to value their mortgage-related securities by the third or fourth quarter of 2007. The notion that marking to market prices was widespread among U.S. banks is simply a myth as far as mortgage-related securities are concerned.

Finally, we examine banks' reported values relative to various benchmarks, including share prices and loss estimates by external parties. We find little empirical evidence that banks' reported fair values suffer from excessive write-downs or undervaluation in 2008, which in turn could have contributed to downward spirals and contagion. If anything, the evidence points in the opposite direction, that is, towards overvaluation, in particular, for assets for which banks have more discretion in determining fair value.

In the conclusion, we point out that, while the claim that fair-value accounting exacerbated the financial crisis appears to be largely unfounded, our study should be interpreted cautiously and not be viewed as advocating an extended use of fair values. It is possible that the role of fairvalue accounting was limited precisely because its use on banks' balance sheets and its relevance for capital requirements were limited. Thus, we need more research on fair-value accounting and, in particular, more empirical evidence to guide regulatory actions or reforms of the accounting rules. Moreover, it is important to recognize that standard setters and bank regulators face many subtle tradeoffs. For instance, even if fair-value accounting were to cause downward spirals and contagion, these negative effects during a crisis have to be weighed against positive effects that fair-value accounting and timely loss recognition likely have, by forcing banks to take prompt corrective actions and by limiting imprudent lending ex ante. 


\section{On The Role of Accounting}

Companies that are publicly traded on a U.S. stock exchange are required by the Securities and Exchange Commission (SEC) to prepare and file quarterly financial statements, which include a balance sheet and an income statement. Financial statements are prepared using "generally accepted accounting principles" (GAAP) and enforced by auditors, the SEC, and private securities litigation. The SEC essentially delegated the task of establishing financial reporting standards to the privately run Financial Accounting Standards Board (FASB). ${ }^{2}$

Broadly speaking, the objective of GAAP is to facilitate financial transactions in markets and contracting in the economy. Financial statements provide standardized information to various parties who use it for investment and credit decisions, to monitor their claims, for private contracting, and regulatory purposes. It is therefore important that accounting numbers are relevant and reliable. However, what is relevant likely differs across users, and relevance and reliability can be in conflict so that the FASB often faces a tradeoff. Bank regulators typically start with banks' financial statements according to GAAP when measuring bank capital and setting capital requirements. But they are not required to use capital according to GAAP, and in some cases they explicitly set up other rules.

\section{How Pure Mark-to-Market Accounting Can Cause Problems in a Crisis}

The most commonly suggested and most plausible mechanism through which fair-value accounting could contribute to a financial crisis involves the link between accounting and bank

2 The FASB is set up as an independent foundation with 16 trustees. These trustees appoint five board members who are the FASB decision-making group; these members are required to sever all other employment ties while serving on the board. The board can draw on an advisory council, staff members, and comment letters from other groups. For details, see FASB website at $<$ http://www.fasb.org/home $>$. 
capital regulation. Market prices can deviate from their fundamental values for various reasons, be it a liquidity crunch or limits to arbitrage (Shleifer and Vishny, 1992, 1997). If a bank has to write down its assets to these distorted prices and, as a result, its regulatory capital is depleted, the write-downs can force the bank to sell assets at fire sale prices and set off a downward spiral. Moreover, if fire-sale prices from a distressed bank become relevant marks for other banks, markto-market accounting can cause write-downs and regulatory capital problems for otherwise sound banks (Cifuentes et al., 2005; Allen and Carletti, 2008; Heaton et al., 2009).

Contagion problems can also arise when management is focused on (short-term) accounting numbers, in particular earnings (for example, because bonuses are based on earnings). In this case, management could be inclined to sell relatively illiquid assets at a price below the fundamental value to pre-empt the anticipated sales of other market participants (Plantin et al., 2008). In doing so, management avoids having to mark the asset to an even lower market price but creates contagion effects for other banks.

These arguments suggest that there are potential problems with pure mark-to-market accounting. However, in practice, the accounting rules do not stipulate pure mark-to-market accounting. Thus, the interesting question is to what extent fair-value accounting, as applied in practice, contributed to the problems in the financial crisis.

\section{How Does Fair-Value Accounting Work in Practice?}

The generally accepted accounting definition of "fair value" is based on rule FAS 157, which was issued by the FASB in 2006. FAS 157 outlines a hierarchy of inputs to derive the fair value of an asset (or liability). Level 1 inputs are quoted prices (from transactions or dealers) in active markets for identical assets. If such prices are available from orderly transactions, they have to be 
used to determine fair value, which means the asset is marked to market. The rule explicitly states that an orderly transaction is not a forced liquidation or distress sale. If Level 1 inputs are not available, models are used to determine fair value (marking-to-model). FAS 157 requires that these models use observable inputs (Level 2), which includes quoted prices for similar assets and other relevant market data (like interest rate yield curves or spreads between related interest rates). Level 3 inputs are unobservable inputs, typically model assumptions, and can be used if observable inputs are not available.

The concept of "fair value" predates the issuance of FAS 157 and many other U.S. accounting standards refer to "fair value" when measuring assets and liabilities. For this reason, even if the specific rules of FAS 157 were suspended, it would not end the practice of fair-value accounting.

\section{Comparison with Historical Cost Accounting}

The main alternative to fair-value accounting is "historical-cost accounting." Here, assets are recorded at historical cost, which generally equals the fair value when the assets are originally purchased. Subsequently, historical costs are adjusted for amortization and impairments, but not for increases in asset values. Impairments have been a part of historical-cost accounting for decades and occur when the fair value of an asset falls below its amortized cost. When asset values decline and impairment is unrestricted, fair-value accounting and historical-cost accounting are conceptually the same. However, in practice, the impairment test differs across assets. Moreover, whether or not the book value of an impaired asset is written down and the loss is recognized in the income statement depends on the asset in question and, in many cases, on whether the impairment is deemed as "other than temporary." 
As long as Level 1 inputs — prices from active markets for the same asset-are available, fairvalue accounting provides little room for manipulation and generally provides reliable information. To the extent that Level 2 inputs have to be used, fair-value accounting offers some discretion to management. With Level 3 inputs, management has considerable discretion. Historical-cost accounting offers little room for manipulation as long as original purchase prices or amortized costs are used, but this information is often criticized for not being relevant (or timely). There is considerable discretion with respect to impairment testing. Moreover, because historical-cost accounting does not recognize gains unless the asset is sold, it may provide incentives for banks to selectively sell (and repurchase) assets that trade in liquid markets and have appreciated in value.

\section{Relevant Accounting Rules for Key Bank Assets}

Accounting rules for financial instruments follow a "mixed-attribute" model, meaning that the accounting treatment differs depending on the type of asset and its intended use (as determined by the reporting entity's management). To guide our discussion of relevant accounting rules for banks' assets, Table 1 provides (asset-weighted) averages for the key assets of U.S. banks (reported values as a fraction of total assets) for the years 2004 to 2006 . We distinguish between large bank holding companies, smaller bank holding companies, and large investment banks (as they existed prior to the financial crisis). The subsequent discussion describes the categories of assets in the table, along with the accounting rules that were in effect during the financial crisis. A summary table of these rules can be found in the appendix.

"Loans and leases" are by far the most important asset class for bank holding companies, and generally account for half or more of these banks' total assets. They can be classified as either "held-for-investment" or "held-for-sale." Held-for-sale loans and leases are carried at the lower 
of historical cost or fair value. In practice, the fraction of loans and leases in this category is typically very small.

For held-for-investment loans and leases, historical-cost accounting applies: they are carried at the principal amount outstanding adjusted for amortization (amortized cost) and are subject to impairment testing. A loan is impaired (according to FAS 114) if it is probable that a creditor will be unable to collect all amounts due. If impaired, the loan is written down to the present value of expected future cash flows. In addition, following FAS 107, banks have to disclose a fair-value estimate for the loans in the notes to their financial statements.

Securities such as U.S. Treasury bills and bonds, obligations of other U.S. government agencies, asset-backed and "structured" securities, bonds, equities, and derivatives can be classified by management as "trading assets" or "other securities."

According to FAS 115, "trading assets" are bought and held principally for the purpose of selling them in the near term. These marketable securities are reported at their fair value and fairvalue changes are recognized in the income statement. Trading assets constitute a substantial fraction of the balance sheet for large investment banks (33 percent) and for large bank holding companies (12 percent), but are unimportant for smaller bank holding companies. Securities that are classified as trading assets by bank holding companies are usually held as part of their brokerage business, market-making, and proprietary trading.

A substantial part of bank holding companies' balance sheet consists of "other securities" that are not held for trading and that are classified (under FAS 115) either as "held-to-maturity" or "available-for-sale." Available-for-sale securities are carried at fair value. Unrealized gains and losses arising from changes in fair value that are viewed as temporary are not recognized in the income statement, but in a separate component of shareholders' equity called "accumulated other 
comprehensive income." However, if such changes are deemed "other-than-temporary," then the asset has to be written-down to its fair value and the loss is recognized in the income statement. ${ }^{3}$

Investments in debt securities are classified as held-to-maturity if the bank has the intent and ability to hold the securities until they mature. Held-to-maturity securities are carried in the balance sheet at historical cost adjusted for amortization. They are subject to (other-thantemporary) impairment testing and banks have to disclose their aggregate fair value in the notes to the financial statements.

A large fraction of investment banks' assets are "collateralized agreements" with brokers, dealers, clearing organizations, and counterparties. They consist of securities purchased under agreements to resell, and securities borrowed. Bank holding companies also have sizeable "repo agreements." These agreements are by their very nature recorded at amounts near fair value, even though they are technically often reported at historical cost (e.g., Nissim and Penman, 2007; SEC, 2008a).

Thus, for large bank holding companies, about 36 percent of assets are reported at or close to fair value; another 50 percent of total assets, primarily loans and held-to-maturity securities, are subject to fair value disclosures in the notes to the financial statements. For investment banks, the fraction of balance sheet assets recorded at fair value tends to be higher as they have large trading books and a substantial amount of collateralized agreements.

3 In response to pressure from Congress and banks, the FASB recently amended the rules for other-thantemporary impairments on debt securities. For fiscal years ending after June 15, 2009, other-than-temporary impairment shall be separated into the amount representing the credit loss and the amount related to all other factors. If the entity does not intend to sell and is unlikely to be required to do so, only the credit loss is recognized in the income statement. 
Among assets recorded at fair value, assets for which Level 2 inputs are used comprise the largest category (mostly models with observable inputs). Both Level 1 inputs (marking-tomarket) and Level 3 inputs play a much smaller role. During the crisis, the fraction of assets with Level 1 inputs decreased, while those valued using models and unobservable inputs (Level 3) increased. Presumably, as the crisis unfolded, fewer assets were traded in active markets, requiring banks to use models to value their assets. We discuss this shift in more detail later.

\section{Did Fair Value Accounting Worsen the Crisis for Investment Banks?}

Starting in 2007, declining house prices, defaults by subprime borrowers, foreclosures, cases of mortgage fraud, and rating downgrades created major problems for mortgage-related securities affecting in particular complex, mortgage-based, "structured" instruments. As housing prices plummeted and mortgage default rates skyrocketed, the market for such securities dried up for reasons unrelated to accounting. There was vast uncertainty over how these securities should be valued, combined with considerable fear of information asymmetries about the quality of the underlying assets and banks' exposures to these securities. Detailed discussions of these problems can be found in Ashcraft and Schuermann (2008), Cox (2008), Rajan et al. (2008), and Gorton (2009).

Many mortgage-related assets were held by investment funds - for example, hedge-funds and "special investment vehicles." As the default risk increased after the onset of the crisis, these investment funds witnessed a huge outflow of capital in the middle of 2007. Several institutions that originated these investment funds, like Bear Stearns and BNP Paribas, stopped withdrawals and disallowed redemptions of their investment funds. They justified this move by arguing that it was impossible to value the assets in the funds as there were "just no prices" for some of the 
securities (Boyd, 2007). But the decision to stop withdrawals was probably also motivated by the fact that these funds had been financed largely with short-term debt and other redeemable funds, and with falling asset values, withdrawals by investors posed severe financial difficulties.

The originators of the investment funds responded to the funds' problems by providing guarantees and secured loans to bail them out. However, by bailing out the investment funds, the institutions effectively assumed their risks and assets. This strategy can be reasonable if the institution believes that the assets are underpriced, perhaps due to a market overreaction, and if the institution has the financial independence to hold on to the assets until the market recovers. In contrast, if the institution that originated the fund is also substantially financed with short-term capital and redeemable funds, it is likely to run into the same problems as investment funds. As even sophisticated players in these markets for structured products, like investment banks and rating agencies, continuously revised their valuations and ratings downward (e.g., Benmelech and Dlugosz, 2009), anxiety among investors increased. For example, after rating downgrades, two hedge funds run by Bear Stearns had problems meeting margin calls and, on June 22, 2007, Bear Stearns committed $\$ 3.2$ billion in secured loans (Brunnermeier, 2009). Only one month later, Bear Stearns revealed that both funds had lost nearly all their value and the funds filed for bankruptcy. In addition to concerns about the fundamentals, investors were worried that banks and the fund managers might misrepresent information to save their funds (Gasparino, 2007). For example, Barclays Bank filed a lawsuit, claiming that they were systematically misled by Bear Stearns about the value of the assets in the funds (Clark, 2007).

Prominent examples of institutions with substantial subprime exposure, either directly or indirectly via investment funds, are Bear Stearns, Merrill Lynch, and Lehman Brothers. Could it be that fair-value accounting played a role in the demise of these investment banks? All three 
institutions experienced bank runs by other large and sophisticated financial institutions and struggled with increased collateral requirements (Morris and Shin, 2008; Brunnermeier, 2009; Gorton and Metrick, 2009). The investment banks tried to sell assets and raise new capital, but in the end were unable to survive.

It seems implausible that a different accounting regime would have helped or saved these investment banks. For investment funds, the need to regularly determine current (or fair) values for their assets is not an accounting issue; it is inevitable given that they are financed with redeemable capital and short-term debt. Given the business model of investment banks and their reliance on short-term debt financing, the issue is not much different. Outside investors would have been concerned about the value of the funds' and investment banks' assets even if the assets had been recorded at historical cost. Thus, it is unlikely that write-downs or fair-value accounting per se played a significant role for the demise of investment funds or investment banks.

Simply revealing severe losses cannot be the issue. The complaint about fair-value accounting would have to be that it forced the investment banks to report losses that were unrealistically large and driven by the short-term uncertainty and lack of liquidity in the market. However, anecdotal evidence suggests that the asset values reported on the three investment banks' balance sheets were too high relative to what the banks could sell the assets for. Fairvalue accounting was not pushing values unreasonably low; instead, it appears that banks were able to overstate their assets in a way that did not help to build confidence. For example, Merrill Lynch sold $\$ 30.6$ billion of collateralized debt obligations backed by mortgages for 22 cents on the dollar, resulting in a pretax loss of $\$ 4.4$ billion (Keoun and Harper, 2008). The loss indicates that, at the time of the sale, the book value of the assets was 65 percent higher than the exit price in the market. Similarly, the hedge fund manager David Einhorn, who sold Lehman's shares 
short, criticized Lehman for overstating the value of their assets as they wrote-down only 3 percent of its $\$ 39$ billion commercial mortgage-backed securities portfolio when an index of commercial mortgage-backed bonds fell 10 percent in the first quarter of 2008 (Onaran, 2008).

It is conceivable that fair-value accounting played a role in the decision of financial institutions to bail out their investment funds. Allegedly, financial institutions feared that selling the investment funds' assets into an illiquid market would have depressed prices and forced writedowns on assets held by their other investment funds or by themselves. This fear of a contagion effect may have played a role in the decision, but we doubt that this was a first-order effect for investment banks. For them, concerns about their reputation if one of their funds fails, as well as fear of further withdrawals of funds, were probably also of great importance. More generally, the financial difficulties of investment banks during the crisis seem to be the result of poor investments, short-term debt financing, high leverage, and investors' concern about the value of the underlying assets, rather than aggressive write-downs forced by fair-value accounting.

It is also unlikely that fair-value accounting fuelled the high leverage prior to the crisis. Adrian and Shin (2009) find a strong positive association between leverage and total assets for investment banks (but not for commercial banks), but this effect seems to be largely driven by short-term collateralized borrowing such as collateralized repurchase agreements. The level of debt that can be obtained by collateralized borrowing depends on the market value of the assets used as collateral (not their book value) and on the level of the haircut demanded in the marketplace. The fact that haircuts increase in a downturn directly results in procyclical leverage (Morris and Shin, 2008). 


\section{Did Fair Value Accounting Worsen the Crisis for Bank Holding Companies?}

According to the American Bankers Association (2009) fair-value accounting is "appropriate for assets that are held for trading purposes or if an entity's business model is based and managed on fair value." However, for traditional commercial banks and for loans, leases, and securities that are held to maturity, the argument goes, fair-value accounting can be inappropriate and misleading, especially in a time of crisis and when markets are illiquid.

However, as we pointed out earlier, banks that focus on traditional lending business can largely avoid the effects of fair-value accounting on their balance sheet or income statement by classifying their loans as held-for-investment. Similarly, for held-to-maturity securities, fairvalue accounting is not required. Indeed, for the 31 bank holding companies that failed and were seized by U.S. bank regulators between January 2007 and July 2009, loans accounted for roughly three quarters of their balance sheets, and trading assets essentially played no role. ${ }^{4}$

Furthermore, we are not convinced by the argument that fair value is not relevant for assets that are held with a long-term perspective. First, even for assets that will be held to maturity, investors might care about assessing a bank's exposure to certain risks or because investors have some doubts that the bank can hold these assets to maturity. This argument does not require the recognition of fair values in the balance sheet, but it suggests that disclosure of fair values in the notes of financial reports is useful. Second, current market values and not the historical costs are important when a bank has to rollover short-term funds or raise new capital. ${ }^{5}$ It is unlikely that

4 Based on 2006 bank regulatory filings using a list of failed banks posted by the Federal Deposit Insurance Corporation. For a similar finding and conclusion see SEC (2008a).

5 The current market value and the liquidity of an asset also play an important role when determining or adjusting margin or collateral requirements. Collateral and margin calls can trigger a downward spiral: that is, increased collateral or margin requirements and falling prices can reinforce each other (Shleifer and Vishny, 1992; 
banks themselves would accept the argument from a borrower negotiating a new mortgage that the current price of a house is not relevant because it is temporarily depressed! Third, bank regulators likely also care about the fair value of a bank's loan portfolio as it provides an estimate of expected future loan losses.

Although deriving fair values can be quite complex in illiquid markets and in times of crisis, it is conceptually difficult to argue that the disclosure of fair-value information per se contributed to uncertainty and exacerbated the financial crisis. Given the known problems in the housing and subprime lending market, it is hard to argue that investors would have not been concerned about bank holding companies had they not disclosed fair-value information. Instead, it is more plausible that less information would have increased investor uncertainty and concerns about adverse selection. In principle, disclosure of fair-value information should mitigate these problems. Moreover, it makes it more difficult for banks to downplay potential problems and hence should act as an early warning system and as a trigger for corrective actions. That is, even if banks' shareholders would have been calmer in the absence of fair-value disclosure, which seems unlikely, there is the concern that, in this case, banks might have had incentives to continue their excessive subprime lending.

Thus, in order to make a case that fair-value accounting contributed to the severity of the crisis, we need to go beyond information effects and look for effects on bank holding companies' actions because fair-value accounting affects the balance sheet, income statement or regulatory capital. In this regard, it is important to recall that, for bank holding companies, the income statement and regulatory capital are already shielded from many fair-value changes.

Brunnermeier and Pedersen, 2009). However, this spiral is not related to the accounting system; it results from the use of market values in bilateral contracts. 
The biggest position on bank balance sheets, the held-for-investment loan portfolio, is not subject to fair-value accounting on either the balance sheet or income statement and it is subject to weaker impairment standards. In the second biggest category, available-for-sale securities, fairvalue accounting plays a limited role: fair-value changes are recognized only in "other comprehensive income," but not in the income statement, unless the asset is sold or other than temporarily impaired. Moreover, fair value changes of available-for-sale debt securities do not affect a bank's regulatory capital unless the asset is sold or other than temporarily impaired. If the bank has the intent and ability to retain the asset for a period of time sufficient to allow for a recovery of the market prices, then it can treat the losses as temporary, and thereby avoid the effect of fair-value losses of available-for-sale debt securities on its income and regulatory capital.

Indeed, during the crisis, many banks initially argued that the uncertainty related to mortgage-backed and other securities was temporary and that they had the intent and ability to retain the securities for a sufficient period of time to allow for a recovery in the market (Krumwiede et al., 2008). For example, Citigroup did not recognize that losses on available-forsale and held-to-maturity securities were "other than temporary" until the fourth quarter of 2008 and even then the amount of the recognized losses was small ( $\$ 2.8$ billion) compared to the unrealized losses on these securities of $\$ 19$ billion (Citigroup, 10-K 2008, pp. 151 and 158). ${ }^{6}$

Thus, even for the largest position recorded at fair value, that is, available-for-sale securities, the income statement and regulatory capital were shielded from fair-value changes in precisely those cases for which banks argued during the crisis that fair-value accounting was not

6 This role of "other than temporary" impairments in shielding banks' income statements and regulatory capital from losses also explains the increasing pressure on the FASB in early in 2009 to ease both impairment and fairvalue rules before banks needed to issue their first quarter financial reports. By that time it became increasingly difficult for banks to keep up the argument that losses on securities were only temporary. 
appropriate and should be suspended: when a decline in market prices, a decrease in liquidity, or an increase in the risk premium is deemed temporary (or an overreaction) and when the bank has the intent and ability to hold on to the asset.

The only remaining position with a direct impact on net income and regulatory capital is the trading book. Here, even the American Bankers Association argues that fair-value accounting is appropriate. Moreover, there are only few very large bank holding companies that have substantial trading portfolios, which they usually hold as part of their investment banking activities. But we nevertheless take a closer look at this link as these trading portfolios caused huge losses for some of these banks. For example, Citigroup suffered a trading loss of more than \$26 billion in 2008, which equals more than 7 percent of the value of their net trading assets and 19 percent of their total regulatory (Tier 1 and Tier 2) capital at the beginning of 2008 . We therefore ask in the remainder of the paper whether, in such cases, write-downs for trading assets could have contributed to downward spirals and, more generally, whether marking to distorted market prices for trading assets may have lead to contagion effects.

\section{Is There Evidence That Market Prices Were Distorted?}

An important question for the debate is to what extent market prices were indeed distorted during the crisis. Unfortunately this question is very difficult to answer. For example, the Bank of England's Stability Report in April 2008 estimated that ABX indices, which provide price benchmarks for securities backed by home equity loans, overstate losses by over 20 percent relative to loss estimates based on projected delinquency rates and increased expectations of credit losses. However, ABX indices continued to fall and in October 2009 were still trading considerably below what they had been trading at the time of the Bank of England report, even 
though the crisis is now widely viewed as contained and equity market prices have risen by more than 30 percent from their lows. Thus, it is not obvious that ABX prices in April 2008 overestimated expected credit losses on securities backed by home equity loans.

Fender and Scheicher (2008) find that increased risk aversion and market illiquidity played a role in the decline of $\mathrm{ABX}$ prices, but these factors are also relevant for fundamental values. Similarly, large bid-ask spreads are often cited as evidence for market distortions and then used to criticize fair-value accounting because fair value is defined as an exit (or bid) price. However, it is important to ask why the spread is large. If, for example, the bid-ask spread of an asset-backed security reflects that bank managers are unwilling to sell because they gamble for resurrection (Diamond and Rajan, 2009), the bid price can still be close to the fundamental value and hence be appropriate.

Systematic empirical analyses of potential market distortions during the crisis are just emerging. Coval et al. (2009) examine the pricing of investment-grade credit risk during the crisis (using cash bond spreads and credit derivative spreads). They conclude that the re-pricing of credit risk appears consistent with the decline in the equity market, an increase in its volatility, and a better pricing of the risks embedded in structured products. They find little evidence suggesting that the dramatic widening of the credit spreads during the crisis is driven by fire sales; if anything, it corrected mispricing prior to the crisis. ${ }^{7}$ Similarly, Longstaff and Myers (2009) find that bank equity prices and equity tranches from collateralized debt obligations were priced consistently between 2004 and 2009. While both studies cast doubt on the notion that prices in the credit markets were systematically distorted, both studies perform their analyses relative to the

7 Friewald et al. (2009) find that liquidity measures explain market-wide corporate yield spread changes even after accounting for credit risk, suggesting that liquidity does play a role in the pricing. But as noted above, liquidity can be a factor in pricing fundamentals. 
pricing in the equity markets. Thus, it is possible that both equity and credit markets were mispriced. More research is necessary to settle this issue.

\section{Safeguards and Circuit-Breakers in Fair-Value Accounting Standards}

Given that distortions of market prices are possible, it is important to recognize that even for trading assets FAS 157 does not require strict marking to market prices under all circumstances. Fair-value accounting as stipulated by the FASB has several safeguards against marking to potentially distorted market prices (including dealer quotes) and hence against accountinginduced downward spirals and contagion.

First, the rule explicitly states that prices from a forced liquidation or distress sale should not be used in determining fair value. Thus, if fire sales occur, banks should not mark their assets to these prices, which amounts to a "circuit breaker" in the downward spiral. In practice, it can of course be difficult to identify prices that stem from fire sales but the rule gives banks a legitimate reason to discard certain prices.

Second, banks choose how to classify their securities at the outset (FAS 115). This classification determines which assets are in banks' trading books and gives them some ex-ante discretion over the extent to which fair value changes affect net income and regulatory capital. Furthermore, in rare circumstances, banks can re-classify and transfer financial instruments from one category to another. For example, in the fourth quarter of 2008, Citigroup re-classified debt securities with a carrying value of approximately $\$ 60$ billion to held-to-maturity; in this way, Citigroup was able to limit the negative effect of further declines in fair value on net income or shareholders' equity. However, the interpretation of circumstances that justify a re-classification is quite strict. Indeed, it is often argued that the SEC did not permit re-classifications until the 
third quarter of 2008 and hence well into the crisis. ${ }^{8}$ Another issue is that when banks have transferred asses to the held-to-maturity category, they are not allowed to sell these securities or re-classify them again. We are not aware of any other major U.S. bank holding company using re-classifications.

Third, when markets become inactive and transaction prices are no longer available, banks are not forced to use dealer quotes that are distorted by illiquidity. In such cases, FAS 157 explicitly allows banks to use valuation models to derive fair values. As the financial crisis deepened, banks used this option. Of all the assets reported at fair value in the first quarter of 2007, bank holding companies used Level 1 inputs (quoted prices) for 34 percent of them; by the first quarter of 2009, this fraction decreased to 19 percent. For bank holding companies, most of the decline in Level 1 assets appears to be compensated by an increase in Level 2 assets, although Level 3 assets increase from about 9 to 13 percent (Table 3). For investment banks, Level 3 assets also increase to 14 percent, mirroring a decline in Level 1 assets from 27 to 22 percent.

As the changes over quarters are also affected by sales and purchases, we also examine net transfers into the Level 3 category, which have to be reported separately. We find that net transfers into the Level 3 category were substantial, but more importantly, they took place early in the crisis. Table 3 reports that, by the first quarter of 2008, the cumulative net transfers into Level 3 amounts to over 40 percent for investment banks and to over 80 percent for the bank holding companies, relative to the original balance of Level 3 assets in the first quarter of 2007 . The numbers are even more striking for those banks that were hit the most during the crisis. For Bear Stearns, Lehman and Merrill Lynch, the cumulative Level 3 transfers by the first quarter of 2008

8 For example, see "Accounting rules only fair" at $<$ http://www.worldfinance.com/news/corporatepractices/financialregulation>. 
amount to over $70 \%$ of the pre-crisis balance, and Citigroup transferred $\$ 53$ billion into Level 3 from the third quarter 2007 to the first quarter of 2008 alone.

While this evidence clearly shows that banks were able to use unobservable inputs and models in determining fair values, even early in the crisis, it is difficult to assess whether they used them enough to avoid contagion effects. The rules are quite restrictive as to when it is possible to deviate from observable market prices. For instance, SEC (2008b) and FASB (2008) emphasize that, while managers can use models and unobservable inputs, they cannot ignore (information contained in) market prices or dealer quotes, and they also stress that illiquid markets are not necessarily a reason to deviate from prices or quotes. The fundamental difficulty for standard setter is that managers have an information advantage over auditors and regulators, which in turn makes it difficult to write accounting standards that provide flexibility when it is needed but that also constrain managers' behaviour when flexibility is used opportunistically. As a result of this trade-off, accounting standards that at times may be overly restrictive are the price that must be paid for rules that require timely write-offs when assets are impaired (Laux and Leuz, 2009).

But even accounting for this trade-off, it is possible that the rules as well as SEC and FASB guidance were too restrictive and that the economy would have benefited from giving managers more flexibility in the crisis. ${ }^{9}$ Perhaps consistent with this view, the FASB relaxed the condition for moving assets into Level 3 in April 2009. But it should be noted that this move was largely the result of political pressure and that joint FASB/SEC guidance issued in September 2008 and

9 Wallison (2008a) and others have viewed the SEC (2008b) guidance on fair-value accounting issued in March 2008 as having exacerbated the problem. A report by Goldman Sachs (2008) issued at the time illustrates the uncertainty surrounding the SEC guidance in March, but the report concludes that the SEC did not tighten the standards or their implementation. However, the uncertainty about the intention of the guidance (coupled with litigation concerns) may have been enough to deter some preparers from deviating from market prices. 
the FASB Staff Position (FAS 157-3) issued in October 2008 already stated that adjustments to observable inputs and market prices may be necessary and should be considered.

More importantly, the notes to banks' financial statements reveal that mortgage-related assets, which were at the heart of the financial crisis, are rarely Level 1 assets. At the beginning of the crisis, banks typically reported them as Level 2 or Level 3 assets, and many moved them to Level 3 early in the crisis. For instance, Citigroup moved to an "intrinsic cash-flow methodology" to value their mortgage-related securities by the fourth quarter of 2007. JP Morgan reports in the fourth quarter of 2008 that "the majority of collateralized mortgage and debt obligations, high-yield debt securities and asset-backed securities are currently classified in Level 3." Thus, the "problem assets" of this crisis were largely marked to models and the notion of directly marking to market prices is a myth as far as mortgage-related securities are concerned.

\section{Empirical Studies on Banks' Financial Reporting and Evidence on Excessive Write-Downs}

Our analysis up to this point indicates that banks had considerable discretion in determining the fair value of their securities. This discretion should have enabled them to avoid marking to distorted Level 1 inputs, be it market prices or dealer quotes, for example, by marking to cashflow models. But widespread use of models alone would not be enough if bank were still forced to mark down Level 2 and Level 3 assets excessively (say, by using high market discount rates for fear of litigation or because of strict auditing). We therefore ask whether there is evidence that reported fair values were too low and banks' write-downs excessive. Empirical evidence that speaks to this question is just beginning to emerge in the academic literature.

Goh et al. (2009), Kolev (2009), and Song et al. (2009) analyze the market pricing of banks' fair-value assets as implied by their share prices relative to other assets and across fair-value input 
categories. While the point estimates differ across studies (due to different samples and specifications), there is little evidence that market valuations of the fair-value assets in 2008 exceeded their reported values, which might indicate excessive write-downs. ${ }^{10}$ More importantly, all three studies find that investors priced a reported $\$ 1$ of Level 3 assets significantly below a reported $\$ 1$ of Level 1 assets. The discount relative to Level 1 assets ranges between 20 and 30 percent. Furthermore, the three studies show that the relative discount of Level 3 assets is smaller when the reported values are likely to be more credible, that is, for firms using Big Four auditors, external valuations, having several financial experts on the audit committee, and for firms with independent board members and strong internal controls. The relative discount of Level 3 assets also increases for banks with less regulatory capital (Goh et al., 2009).

There are several possible explanations for these findings. One explanation is that banks' valuations based on unobservable Level 3 inputs are upwardly biased and overstate the value of these assets. But the discount can also be driven by factors that enter market pricing but not banks' fair-value estimates. For instance, it is possible that investors apply larger discount factors to the reported Level 3 fair values because they stem from valuation models with unobservable inputs and hence are subject to more model risk (or noise) and larger information asymmetry. The lower market pricing of Level 3 assets could also reflect an expectation that, because these assets are very illiquid (compared to Level 1 assets), they would have to be sold at deep discounts if banks had to engage in asset-fire sales. While investors would be expected to price such an expectation, under the existing accounting rules, banks' reported fair values would not capture such fire-sale discounts (and therefore would not be overstated).

10 As an example, assume that a bank can hold an asset until maturity with a positive probability, but fair value accounting requires the bank to mark the asset to a price that is distorted by asset-fire sales or a high liquidity discount. In this case, the market should value the asset above the bank's reported value, reflecting the positive probability that the bank will not have to sell at the distorted price and may realize a higher value in the future. 
The three aforementioned studies cannot distinguish between these explanations. ${ }^{11}$ However, it should be noted that, even if expected fire sales explain the discount of Level 3 assets, the results imply that banks were able to report fair values well above the (expected) fire-sale prices of these assets and that the discount exists nevertheless, which casts doubt that the reported fair values played a role in creating the fire-sale expectation in the first place.

To distinguish between explanations, it would be interesting to look at how the market pricing of reported fair values changed in the fourth quarter of 2008 as banks received government guarantees and other forms of support that made fire sales less likely. If the discount of Level 3 assets in the first three quarters of 2008 declined in subsequent quarters, this would point towards the fire-sale explanation. If in turn the discount relative to Level 1 assets remained or even increased, the fire-sale explanation is unlikely. Unfortunately, the studies do not yet provide this analysis. ${ }^{12}$ However, it is possible to examine banks' market-to-book ratios instead. A bank's book value equals the value of its assets net of its liabilities; hence, the market-to-book ratio is an indication of the market pricing of reported net assets. This approach clearly has limitations but it may provide a first indication.

Table 4 reports market-to-book ratios from the first quarter of 2007 to the first quarter of 2009 for a sample of seven major U.S. investment banks and bank holding companies. Prior to the crisis, market-to-book ratios are on average around two for both types of banks. Throughout the crisis, market-to-book ratios fall and by the fourth quarter of 2008 , the ratios are below one.

11 In addition, it is possible that the results reflect unobserved heterogeneity in bank strategies or business models that is correlated with their fair-value allocations across levels. It helps, however, that Goh et al. (2009) find similar results in changes.

12 Interestingly, Goh et al. (2009) also show that the market pricing of other assets (not reported at fair value) declined over the first three quarters in 2008, and seemingly more so than for the assets recorded at fair value. These other assets are largely loans for which the fire-sale explanation is less likely. 
In the first quarter of 2009 , the market-to-book ratios are below 0.9 for the two remaining investment banks and below 0.5 for the bank holding companies. Thus, despite the fact that banks' franchise values are generally positive and not recorded on the balance sheet, investors appear to value banks' assets substantially below their reported book value. As before, it is possible that share prices reflect an expectation of distressed sales of banks' assets (for example, to satisfy capital requirements). However, as Table 4 shows, banks' market-to-book ratios continue to fall in the fourth quarter of 2008 and the first quarter of $2009 .^{13}$ The government interventions in October 2008 should have reduced the likelihood of distressed sales of banks' assets into illiquid markets and hence increased the relative pricing if it primarily reflected such fire-sale discounts. While this evidence is only suggestive and hinges on our belief as to whether banks' share prices during the crisis were reasonably efficient, it points more in the direction of overvaluation of banks' assets than towards the fire-sale explanation.

In a similar spirit, Huizinga and Laeven (2009) analyze the market pricing of banks' realestate assets (that is, mortgages and mortgage-backed securities) relative to other bank assets. They find that, starting in 2005, investors discount banks' real-estate loans relative to other assets by 10 percent. In addition, starting in 2008 , there is a 20 percent discount for banks' mortgagebacked securities relative to other securities. This discount does not decline in the fourth quarter of 2008. Moreover, banks with a larger share of mortgage-backed securities and low market-tobook ratios appear to have smaller provisions for future loan losses. Cumulatively, these findings again cast doubts on claims that during the crisis banks were forced to write-down their mortgagerelated assets excessively.

13 It is conceivable that this decline in market-to-book ratios based on common shareholders' equity reflects a wealth transfer from common shareholders to the government, when the government required banks to take on preferred shares as part of the government bailout. But this explanation is unlikely given that Veronesi and Zingales (2008) estimate that the Treasury overpaid for the preferred shares they injected in banks. 
More evidence on banks' reluctance to recognize losses comes from a goodwill impairment study by Disclosure Insight (2009), an independent investment research firm. When a bank acquires another bank, the acquiring bank has to record the premium it paid over the fair value of the acquired bank's assets and liabilities as goodwill on its balance sheets. This goodwill is subject to regular impairment testing and needs to be written down if the fair value of goodwill is below its book value. The study shows that, of the 50 U.S. banks that made substantial acquisitions prior to the financial crisis, 35 banks have not written down their goodwill positions at all, despite the fact that banks' market values have declined precipitously in the crisis. For instance, Bank of America carries over $\$ 80$ billion in goodwill on its 2008 balance sheet, which amounts to $50 \%$ of its shareholders' equity and largely stems from the acquisitions of FleetBoston Financial, MBNA, and LaSalle Bank between 2004 and 2007. Until the second quarter of 2009, Bank of America has not recorded any goodwill impairment. The Disclosure Insight (2009) study provides 15 other examples of banks with "questionable" goodwill treatment. ${ }^{14}$

Our final piece of evidence on banks' reluctance to report losses is based on fair-value disclosures for loans. For loans, we can compare loan losses implied by bank reporting with external estimates of loan losses. This comparison does not rely on market prices and hence the result cannot be explained by distorted market prices. According to FAS 107, banks have to disclose the fair value of their financial instruments, even if these instruments are carried on the balance sheet at amortized costs like loans. Thus, for loans, we can compute the difference between the value at amortized costs (net of the allowance for loan losses) and the fair value. This difference plus the allowance for loan losses can be viewed as the reported estimate for

14 Ramanna and Watts (2009) provide similar evidence on firms' reluctance to impair goodwill based on a broader sample. 
expected loan losses. ${ }^{15}$ This estimate should be an upper bound on the expected loan losses, if fair-value accounting forces banks to use exit values for the loans that are substantially below their fundamental values, as is often claimed. We can then compare this reported estimate with the expected loan losses estimated by external parties.

We use external loan loss estimates for the four largest U.S. bank holding companies from four different reports that were released shortly after banks released their 2008 financial statements (Board of Governors, 2009; Citigroup, 2009; Citadel, 2009; Goldman Sachs, 2009). The first estimate is from the Supervisory Capital Assessment Program (SCAP) - the regulatory program to evaluate whether financial institutions had enough capital, known as the "stress test." It covers expected loan losses on the 2008 year-end portfolio over the next two years in the "more adverse" scenario. The second estimate is from a Citigroup analyst report. It predicts loan losses over four years on the portfolio held at end of 2007. We adjust the four-year estimate by subtracting the losses estimated for 2008. The remaining two loss estimates by Goldman Sachs and Citadel are computed by multiplying the projected loss rates for each loan category by the loans held in that category.

Table 5 shows that banks' reported estimates of the expected loan losses, as implied by the difference between the loans' amortized cost (first column) and their fair value (second column) plus the loan loss allowance (third column), is much smaller than the respective loss estimates by external parties for all four banks. The lowest external estimate for each bank exceeds the reported estimate by over 45 percent (Wells Fargo) up to 76 percent (Bank of America), and

15 The allowance for loan losses by itself is an insufficient estimate of the expected future loan losses because, as described earlier, it is not based on a comparison of the fair value with the carrying value of the loans. In addition, there is empirical evidence that banks manage their allowance for loan losses and that banks' loan loss provisions in times of distress are too small. See, for example, Beatty et al. (1995), Liu and Ryan (1995), Ahmed et al. (1999), and Laeven and Majnoni (2003). 
several external estimates exceed the implied loss estimate reported by the banks by a factor of three. One potential criticism of this comparison is that several of the external estimates are based on or at least influenced by the assumptions used for the regulatory "stress tests," which were meant to be conservative. However, as noted by the financial press, the "adverse scenario" of the stress tests looked increasingly likely by April 2009. Moreover, the Goldman Sachs estimates (last column) stem from January 2009 and predate the announcement of the stress tests. Finally, banks' reported loss estimates appear too low when we gauge them against loan loss estimates in the IMF Stability Report from April 2009.

In sum, there is little evidence that banks' reported fair values suffer from excessive writedowns or undervaluation in 2008. If anything, the evidence points in the opposite direction, suggesting that banks used the discretion in the accounting rules to keep asset values high relative to concurrent market prices and expectations. More research is needed to determine whether these findings indeed imply that banks are overstating their assets.

\section{Conclusion}

Many have called for a suspension or substantial reform of fair-value accounting because it is perceived to have contributed to the severity of the 2008 financial crisis. This criticism and the ensuing political interference by the European Commission and U.S. congress have put considerable pressure on the accounting standard setters to relax the rules.

Based on existing evidence, we have little reason to believe that fair-value accounting contributed to banks' problems in the financial crisis. Fair values play only a limited role for banks' income statements and regulatory capital ratios, except for a few banks with large trading positions. For these banks, investors would have worried about exposures to subprime mortgages 
and made their own judgments, even in the absence of fair-value disclosures. Moreover, extant rules have various safeguards and offer substantial discretion to banks, which allows them to avoid marking to distorted market prices. Banks used this flexibility during the crisis. There is also little evidence that prices were in fact distorted due to asset-fire sales or that banks were forced to take excessive write-downs during the crisis.

While we believe that the claim that fair-value accounting exacerbated the crisis is largely unfounded, our conclusions have to be interpreted cautiously and should not be viewed as advocating an extension of fair-value accounting. However, given the paucity of evidence that fair-value accounting was in any substantial way responsible for either the weakening of banks or causing contagion between banks, the case for loosening the existing fair-value accounting rules is equally weak (see also SEC, 2008a). We need more research to understand the effects of fairvalue accounting in booms and busts to guide efforts to reform the rules. ${ }^{16}$

Fair-value accounting loses many of its desirable properties when prices from active markets are no longer available and hence models have to be used. Therefore, it is certainly possible that fair-value accounting rules and the details of their implementation could be further improved. However, standard setters face several thorny tradeoffs, which we discuss in greater detail in Laux and Leuz (2009). First, relaxing the rules or giving management more flexibility to avoid potential problems of fair-value accounting in times of crisis also opens the door for manipulation and can decrease the reliability of the accounting information at a critical time. One read of the

16 An interesting study in this regard is Khan (2009). He examines contagion effects in banks' equity returns and whether contagion occurs more frequently in periods with higher use of fair-value accounting. While he finds evidence consistent with this conjecture, it should be interpreted cautiously. As the use of fair-value has been steadily increasing over time, the results could also reflect increasing trends toward other factors that can cause contagion, such as more transactions with margin requirements or more ratings-based structured products. Furthermore, the results do not imply contagion in the markets of those assets that are reported at fair value. 
empirical evidence on bank accounting during the crisis is that investors believed that banks used accounting discretion to substantially overstate the value of their assets. The resulting lack of transparency about banks' solvency could be a bigger problem in crises than potential contagion effects from a stricter implementation of fair-value accounting.

Second, even if (stricter) fair-value accounting were to contribute to downward spirals and contagion, these negative effects in times of crisis have to be weighed against the positive effects of fair-value accounting and timely loss recognition. When banks are forced to write down the value of assets as losses occur, they have incentives to take prompt corrective action and to limit imprudent lending in the first place, which ultimately reduces the severity of a crisis. A central lesson of the U.S. savings and loan crisis is that when regulators hold back from requiring financial institutions to confront their losses, the losses can rapidly become much larger (Allen and Carletti, 2008). For the same reason, it is problematic if accounting rules are relaxed or suspended whenever a financial crisis arises because banks can reasonably anticipate such changes, which diminishes their incentives to avoid risks ex ante. Instead, it may be more appropriate to adjust regulatory capital requirements as opposed to change the accounting standards themselves. 


\section{Acknowledgements}

We appreciate helpful comments from David Autor, Chad Jones, Hal Scott, Andrei Shleifer, Doug Skinner, Timothy Taylor, workshop participants at the University of Chicago as well as helpful conversations with Jacob Goldfield, Peter Goldschmidt (PwC), Timothy Schott (KPMG), and Timo Willershausen (PwC). We thank Denis Echtchenko, Frank Li and, in particular, Ashish Shenoy for their excellent research assistance. Christian Laux gratefully acknowledges the hospitality at the University of Chicago Booth School of Business, which he visited while the paper was written, and research funding provided by the Center for Financial Studies (CFS) at the Goethe-University Frankfurt. Christian Leuz gratefully acknowledges the support by the Neubauer Family Faculty Fellowship and the Initiative on Global Markets (IGM) at the University of Chicago Booth School of Business. 


\section{References}

Adrian, Tobias, and Hyun Song Shin. 2008. "Liquidity and Leverage.” Journal of Financial Intermediation, forthcoming.

Ahmed, Anwer, Carolyn Takeda, and Shawn Thomas. 1999. "Bank Loan Loss Provisions: A Reexamination of Capital Management, Earnings Management and Signaling Effects.” Journal of Accounting and Economics, 28(1): 1-25.

Allen, Franklin, and Elena Carletti. 2008. "Mark-to-Market Accounting and Liquidity Pricing." Journal of Accounting and Economics, 45(2-3): 358-378.

American Bankers Association. 2008. "Letter to SEC." September 23.

American Bankers Association. 2009. "Fair Value and Mark to Market Accounting." http://www.aba.com/Issues/Issues_FairValue.htm

Ashcraft, Adam, and Til Schuermann. 2008. "Understanding the Securitization of Subprime Mortgage Credit." Federal Reserve Bank of New York Staff Reports No. 318.

Ball, Ray. 2008. "Don't Blame the Messenger ... or Ignore the Message." http://www.chicagobooth.edu/email/chicago_on/ShootingTheMessenger10.12.2008.pdf

Bank of England. 2008. "Financial Stability Report.” April, Issue No. 23.

Banque de France. 2008. "Valuation and Financial Stability." Financial Stability Review, No. 12, October.

Beatty, Anne, Sandra Chamberlain, and Joseph Magliolo. 1995. "Managing Financial Reports of Commercial Banks: The Influence of Taxes, Regulatory Capital, and Earnings." Journal of Accounting Research, 33(2): 231-161.

Benmelech, Efraim, and Jennifer Dlugosz. 2009. “The Credit Rating Crisis.” NBER Working Paper No. 15045.

Benston, George J. 2008. "The Shortcomings of Fair-Value Accounting Described in SFAS 157." Journal of Accounting and Public Policy, 27(2): 101-114.

Boyd, Sebastian. 2007. "BNP Paribas Freezes Funds as Loan Losses Roil Market.” Bloomberg Press, August 9.

http://www.bloomberg.com/apps/news?pid=20601087\&sid=ayOiMpIOavzw\&refer=home

Board of Governors of the Federal Reserve System. 2009. "The Supervisory Capital Assessment Program (SCAP): Overview of the Results," May.

Brunnermeier, Markus K. 2009. "Deciphering the Liquidity and Credit Crunch 2007-2008." Journal of Economic Perspectives, 23(1): 77-100.

Brunnermeier, Markus K., and Lasse Heje Pedersen. 2009. "Market Liquidity and Funding Liquidity.” Review of Financial Studies, 22(6): 2201-2238.

Cifuentes, Rodrigo, Gianluigi Ferrucci, and Hyun Song Shin. 2005. "Liquidity Risk and Contagion.” Journal of the European Economic Association, 3 (2-3): 556-566.

Citadel. 2009. "Capital Adequacy of the U.S. Banking System," Fixed Income Newsletter, March. 
Citigroup. 2009. "U.S. Banks: Assessing Risk/Reward Under Various Stress Test Scenarios." Citigroup Global Markets, March.

Clark, Andrew. 2007. „Barclays Sues over Sub-Prime Losses”, The Guardian, December 20, http://www.guardian.co.uk/business/2007/dec/20/barclaysbusiness.subprimecrisis

Coval, Joshua D., Jakub W. Jurek, and Erik Stafford. 2009. "The Pricing of Investment Grade Credit Risk During the Financial Crisis."

http://www.usc.edu/schools/business/FBE/seminars/papers/F_4-2-09_COVAL-cjs.pdf

Cox, Christopher. 2008. Statement at Open Meeting on Rules for Credit Rating Agencies. Speech by SEC Chairman. June 11, 2008. http://www.sec.gov/news/speech/2008/spch061108cc.htm

Diamond, Douglas and Raghuram Rajan. 2009. "Fear of Fire Sales and the Credit Freeze." NBER Working Paper 14925. http://www.nber.org/papers/w14925

Disclosure Insight. 2009. "Bank Goodwill Impairment Study.” March.

European Central Bank (ECB). 2004. "Fair Value Accounting and Financial Ftability." Occasional Paper Series, No. 13, April.

Fender, Ingo, and Martin Scheicher. 2008. "The ABX: How Do the Markets Price Subprime Mortgage Risk?” BIS Quarterly Review, September: 67-81.

Financial Accounting Standards Board (FASB). 2008. "Determining the Fair Value of a Financial Asset When the Market for That Asset Is Not Active ." FASB Staff Position, FSP FAS 157-3, October 10. http://www.fasb.org/pdf/fsp fas 157-3.pdf

Friewald, Nils, Rainer Jankowitschy, and Marti Subrahmanyam. 2009. "Illiquidity or Credit Deterioration: A Study of Liquidity in the US Corporate Bond Market during Financial Crises.”SSRN Working Paper Series, No 1420294. http://ssrn.com/abstract=1420294

Forbes, Steve. 2009. "End Mark-to-Market." Forbes.com. March 23.

http://www.forbes.com/2009/03/20/steve-forbes-mark-to-market-intelligent-investingmarket.html

Gasparino, Charlie. 2007. "Two Bear Stearns Hedge Funds 'Essentially Worthless'.” CNBC.com, July 17th. http://www.cnbc.com/id/19807752

Goh, Beng Wee, Jeffrey Ng, and Kevin Ow Yong. 2009. "Market Pricing of Banks' Fair Value Assets Reported Under SFAS 157 During the 2008 Economic Crisis.” SSRN Working Paper Series, No 1335848. http://papers.ssrn.com/sol3/papers.cfm?abstract_id=1335848

Goldman Sachs. 2008. "United States: Portfolio Strategy, Accounting Ledger: SEC issues letter on fair value, Clarifying guidance or material changes?" March.

Goldman Sachs. 2009. "United States: Financial Services - As mortgage loss estimates continue to rise, further policy response likely to follow," January.

Gorton, Gary B. 2009. “The Subprime Panic.” European Financial Management, 15(1): 10-46.

Gorton, Gary B., and Metrick, Andrew. 2009. "Securitized Banking and the Run on Repo." Yale ICF Working Paper No. 09-14. http://ssrn.com/abstract=1440752 
Heaton, John, Deborah Lucas, Robert McDonald. 2009. "Is Mark-to-Market Accounting Destabilizing? Analysis and Implications for Policy." Working Paper.

Huizinga, Harry, and Luc Laeven. 2009. “Accounting Discretion of Banks During a Financial Crisis. SSRN Working Paper Series, No 1434359. http://ssrn.com/abstract=1434359

International Monetary Fund (IMF). 2008. "Chapter 3: Fair Value Accounting and Procyclicality." Global financial stability report, October.

Khan, Urooj. 2009. "Does Fair Value Accounting Contribute to Systemic Risk in the Banking Industry?” SSRN Working Paper Series No 1327596. http://ssrn.com/abstract=1327596

Keoun, Bradley, and Christine Harper. 2008. "Merrill Has \$5.7 Billion of Writedowns, Sells Shares." Bloomberg.com, July $28^{\text {th }}$. http://www.bloomberg.com/apps/news?pid=20601110\&sid=a.qIMphkb5cA

Kolev, Kalin. 2009. "Do Investors Perceive Marking-to-Model as Marking-to-Myth? Early evidence from FAS 157 Disclosure.” SSRN Working paper series No.1336368. http://ssrn.com/abstract=1336368.

Krumwiede, Tim, Ryan M. Scadding, and Craig D. Stevens. 2008. "Mortgage-Backed Securities and Fair-Value Accounting." The CPA Journal. http://www.nysscpa.org/printversions/cpaj/2008/508/p30.htm.

Landsman, Wayne R. 2007. "Is fair value accounting information relevant and reliable? Evidence from capital market research," Accounting and Business Research, Special Issue: International Accounting Policy Forum: 19-30.

Laux, Christian, and Christian Leuz. 2009. "The Crisis of Fair-Value Accounting: Making Sense of the Recent Debate." Accounting, Organizations and Society, 34(6-7), 826-834.

Laeven, Luc, and Giovanni Majnoni. 2003. "Loan Loss Provisioning and Economic Slowdowns: Too Much, Too Late" Journal of Financial Intermediation, 12(2): 178-197.

Liu, Chi-Chun and Stephen Ryan. 1995. "The Effect of Bank Loan Portfolio Composition on the Market Reaction to and Anticipation of Loan Loss Provisions." Journal of Accounting Research, 33(1): 77-94.

Longstaff, Francis A., and Brett Myers. 2009. "Valuing Toxic Assets: An Analysis of CDO Equity.” NBER Working Paper 14871. http://www.nber.org/papers/w14871

Morris, Stephen, and Hyun Song Shin. 2008. "Financial Regulation in a System Context." Brooking Papers on Economic Activity, Fall: 229-261.

Nissim, Doron, and Stephen Penman. 2007. "Fair Value Accounting in the Banking Industry." Center for Excellence in Accounting and Security Analysis Occasional Paper Series.

Onaran, Yalman. 2008. "Lehman Cuts \$130 Billion of Assets to End Bear Stigma." Bloomberg.com, June $8^{\text {th }}$. http://www.bloomberg.com/apps/news?pid=20601087\&sid=aUaJYcbwzbjI\&

Penman, Stephen. H. 2007. "Financial Reporting Quality: Is Fair Value a Plus or a Minus?" Accounting and Business Research, Special Issue: International Accounting Policy Forum: $33-44$. 
Plantin, Guillaume, Haresh Sapra, and Hyun Song Shin. 2008. "Marking-to-Market: Panacea or Pandora's Box?” Journal of Accounting Research, 46(2): 435-460.

Rajan, Uday, Amit Seru, and Vikrant Vig. 2008. "The Failure of Models That Predict Failure: Distance, Incentives and Defaults." Chicago Graduate School of Business Research Paper No. 08-19.

Ramanna, Karthik, and Watts, Ross L. 2009. "Evidence from Goodwill Non-Impairments on the Effects of Using Unverifiable Estimates in Financial Reporting." Harvard Business School Accounting \& Management Unit Working Paper No. 09-106. http://ssrn.com/abstract $=1134943$

Ryan, Stephen G. 2008. "Accounting in and for the Subprime Crisis." The Accounting Review, 83(6): 1605-1638.

Securities and Exchange Commission (SEC). 2008a. "Report and Recommendations Pursuant to Section 133 of the Emergency Economic Stabilization Act of 2008: Study on Mark-to-Market Accounting.

Securities and Exchange Commission (SEC). 2008b. "Sample Letter Sent to Public Companies on MD\&A Disclosure Regarding the Application of SFAS 157 (Fair Value Measurements)." March 2008.

Shleifer, Andrei, and Robert W. Vishny. 1992. "Liquidation Values and Debt Capacity: A Market Equilibrium Approach.” Journal of Finance, 47(4): 1343-1366.

Shleifer, Andrei, and Robert W. Vishny. 1997. "The Limits of Arbitrage." Journal of Finance, 52(1): 35-55.

Song, Chang J., Wayne B. Thomas, and Han Yi. 2009. "Value Relevance of FAS 157 Fair Value Hierarchy Information and the Impact of Corporate Governance Mechanisms." SSRN Working Paper Series No 1198142. http://ssrn.com/abstract=1198142.

Turner, Lynn. 2008. "Banks Want to Shoot the Messenger over Fair Value Rules." Financial Times, October 2: 17.

Veron, Nicolas. 2008. "Fair Value Accounting is the Wrong Scapegoat for this Crisis". European Accounting Review, 5(2): 63-69.

Veronesi, Pietro, and Luigi Zingales. 2008. "Paulson's Gift." http://faculty.chicagobooth.edu/brian.barry/igm/P_gift.pdf.

Wallison, Peter J. 2008a. "Fair Value Accounting: A Critique." American Enterprise Institute for Public Policy Research Outlook Series, July.

Wallison, Peter J. 2008b. "Judgment too Important to be Left to the Accountants." Financial Times, May 1.

Whalen, R. Christopher. 2008. "The Subprime Crisis - Causes, Effect and Consequences." Networks Financial Institute Policy Brief No. 2008-PB-04, March. http://ssrn.com/abstract $=1113888$ 


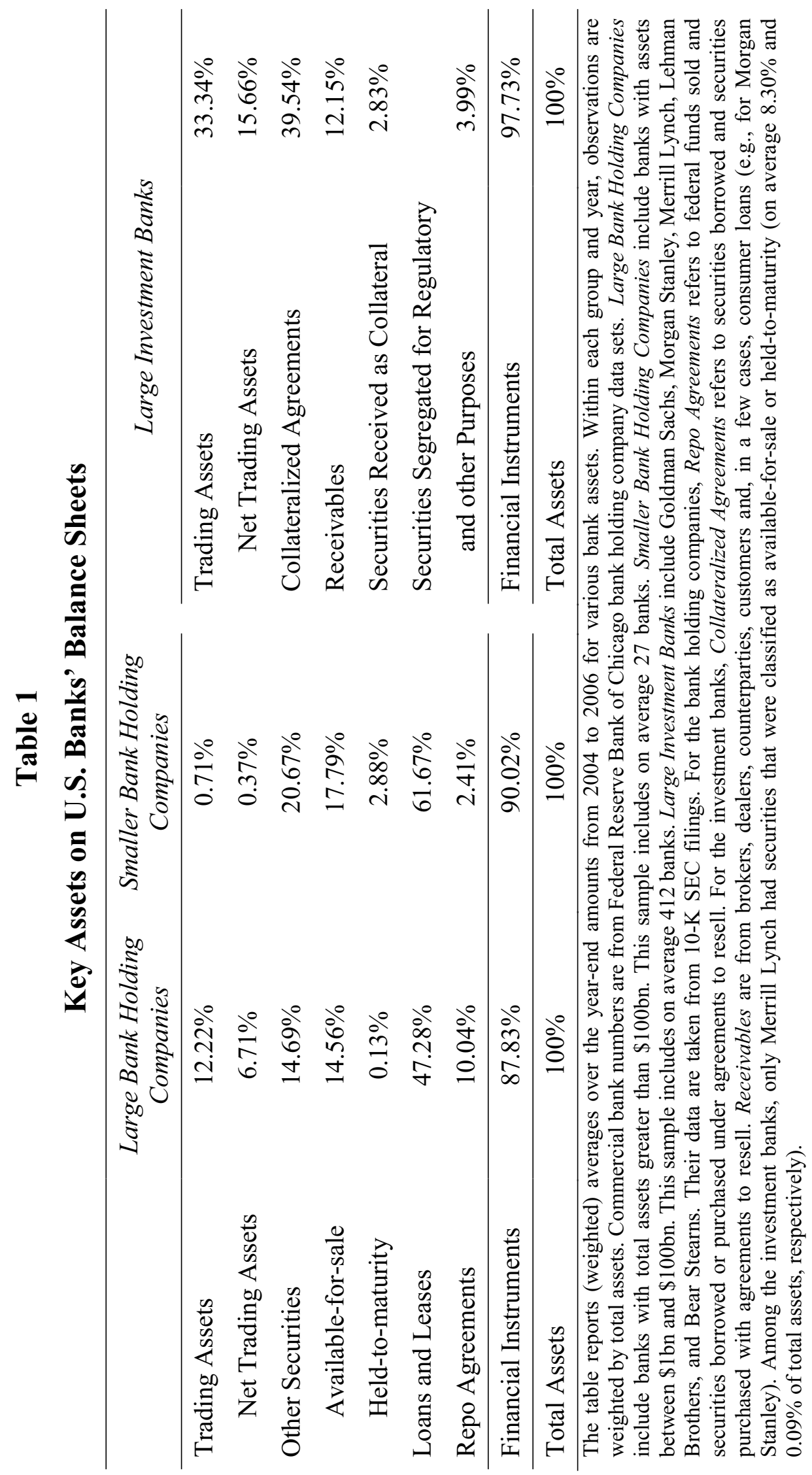

$n$ 


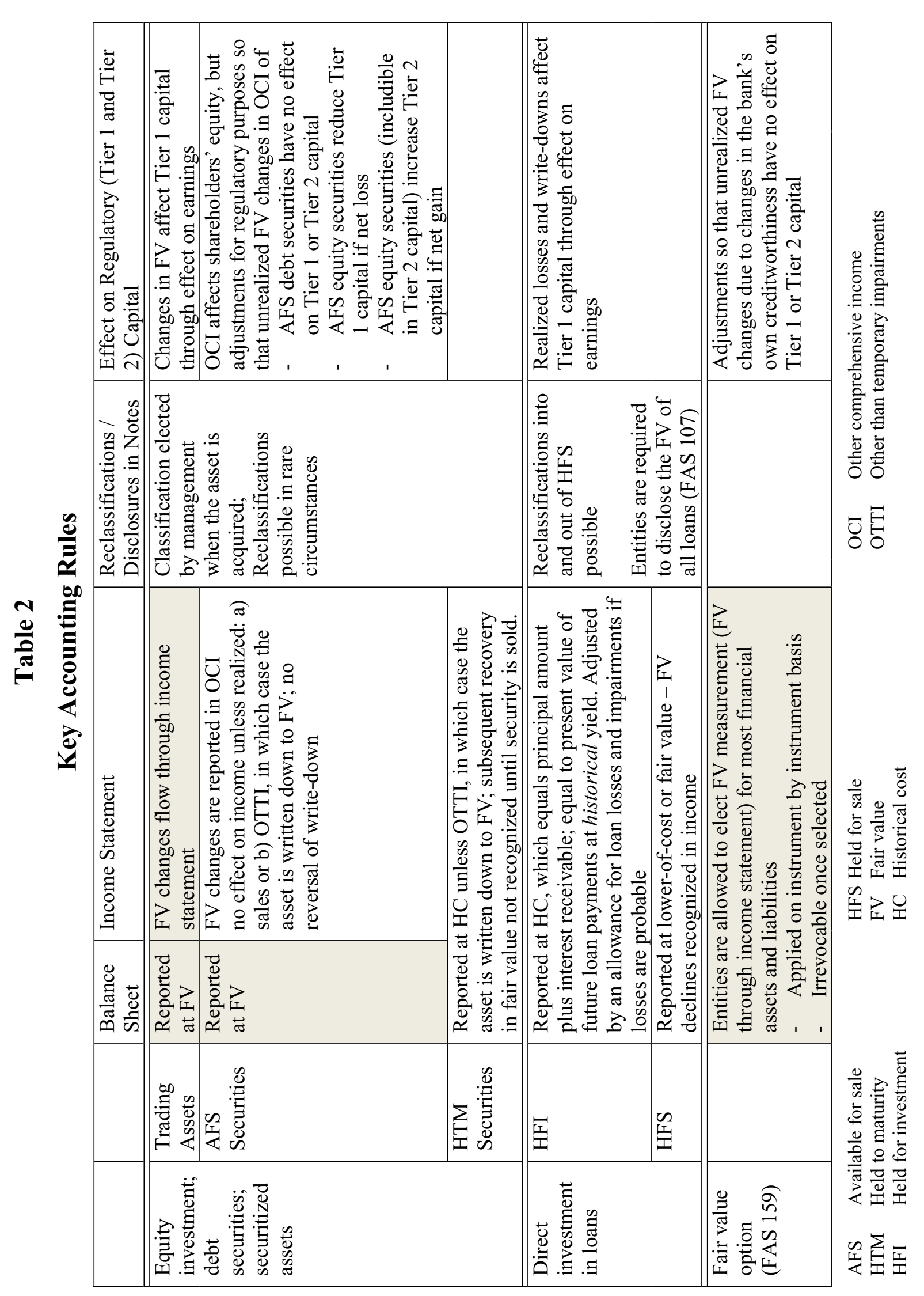




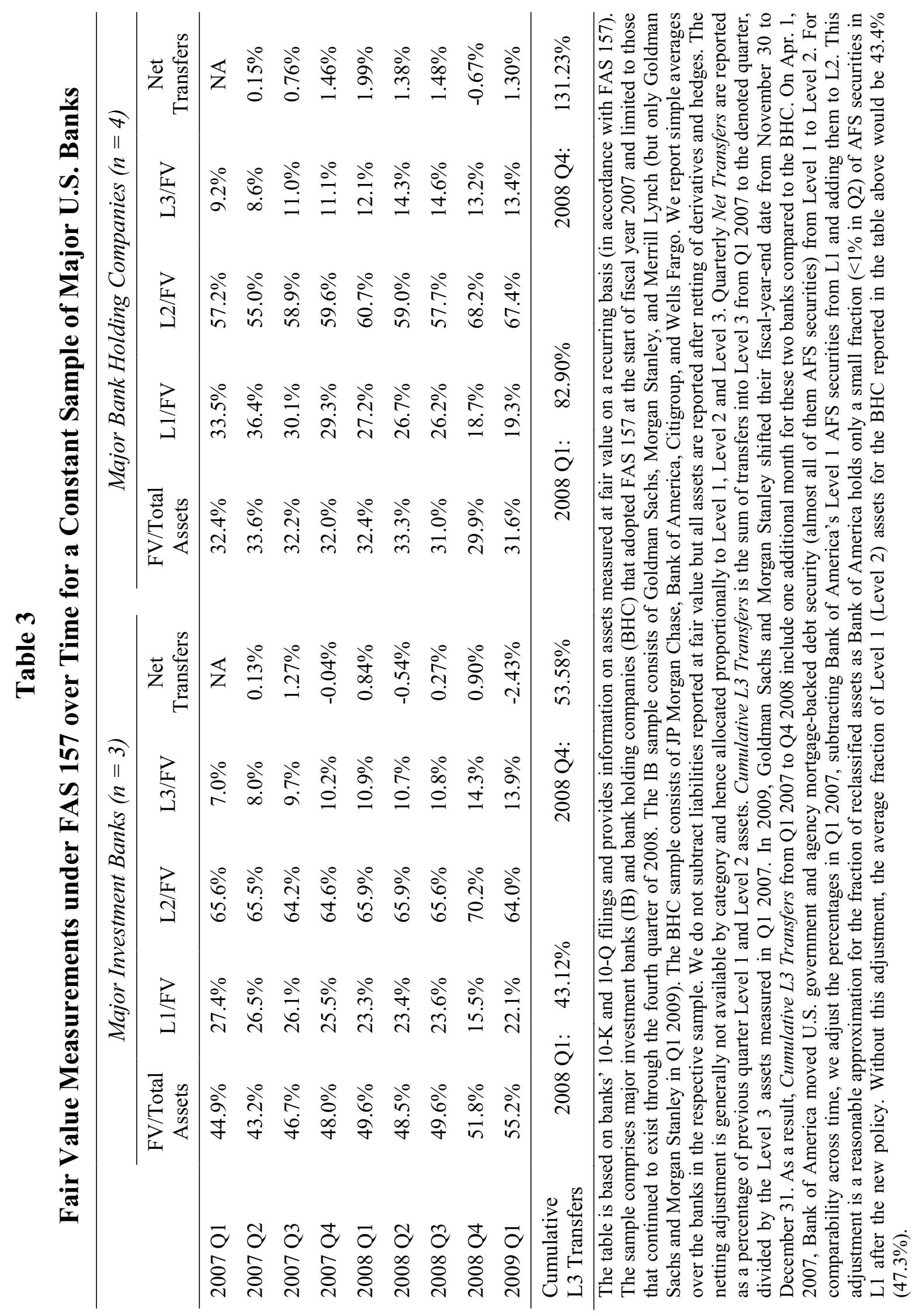

nิ 
Table 4

Market-to-Book Ratios for Common Shareholders' Equity over Time

\begin{tabular}{|c|c|c|c|c|}
\hline & \multicolumn{2}{|c|}{ Major U.S. Investment Banks } & \multicolumn{2}{|c|}{$\begin{array}{c}\text { Largest U.S. Bank Holding } \\
\text { Companies }\end{array}$} \\
\hline & Mean & Median & Mean & Median \\
\hline 2007 Q1 & 2.24 & 2.26 & 2.08 & 2.00 \\
\hline 2007 Q2 & 2.26 & 2.31 & 1.96 & 1.90 \\
\hline 2007 Q3 & 2.08 & 1.95 & 1.90 & 1.82 \\
\hline 2007 Q4 & 1.92 & 1.86 & 1.55 & 1.35 \\
\hline 2008 Q1 & 1.53 & 1.50 & 1.42 & 1.25 \\
\hline 2008 Q2 & 1.39 & 1.29 & 1.06 & 0.88 \\
\hline 2008 Q3 & 1.08 & 1.24 & $1.08 *$ & $1.12 *$ \\
\hline 2008 Q4 & 0.94 & 0.73 & 0.90 & 0.66 \\
\hline 2009 Q1 & 0.86 & 0.86 & 0.45 & 0.43 \\
\hline
\end{tabular}

The table reports market-to-book ratios for banks' common shareholders' equity from the first quarter of 2007 to the first quarter of 2009. The sample contains three major investment banks (Goldman Sachs, Morgan Stanley, Merrill Lynch; except for the first quarter of 2009 when Merrill Lynch was already part of Bank of America) and the four largest bank holding companies (Bank of America, Citigroup, JP Morgan, Wells Fargo). The ratios are computed as the total market value of outstanding common shares at the fiscal quarter end divided by the contemporaneous total book value of common shareholders' equity. * indicates that in the third quarter of 2008, the market value of Wells Fargo stock included the pending takeover of Wachovia. We adjusted the book value of Wells Fargo accordingly by adding the book value of Wachovia Bank. 


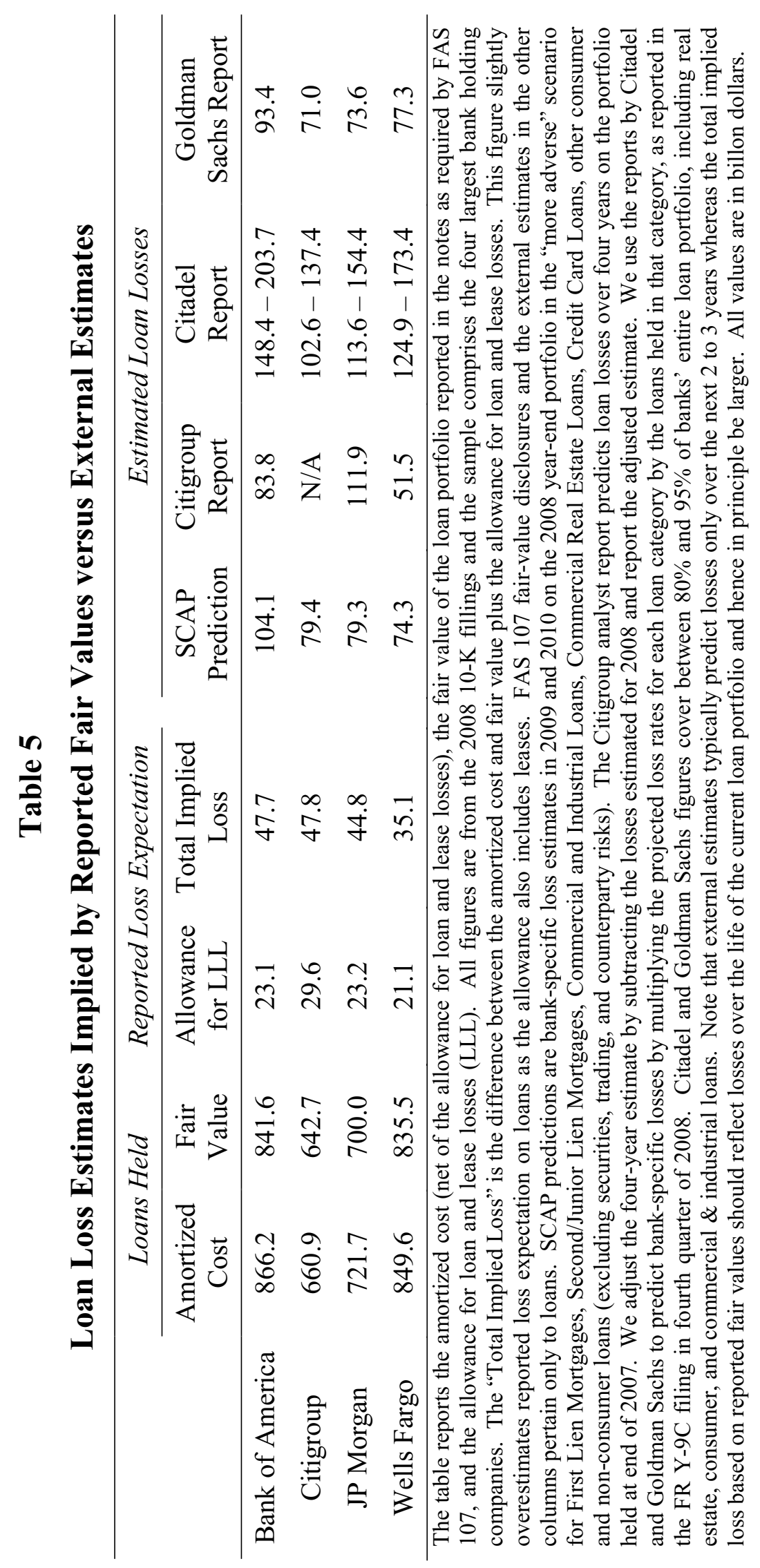




\section{CFS Working Paper Series:}

\begin{tabular}{|c|c|c|}
\hline No. & Author(s) & Title \\
\hline $2009 / 21$ & $\begin{array}{l}\text { John B. Taylor } \\
\text { Volker Wieland }\end{array}$ & $\begin{array}{l}\text { Surprising Comparative Properties of } \\
\text { Monetary Models: Results from a New Data } \\
\text { Base }\end{array}$ \\
\hline $2009 / 20$ & $\begin{array}{l}\text { Nikolaus Hautsch } \\
\text { Lada M. Kyj } \\
\text { Roel C.A. Oomen }\end{array}$ & $\begin{array}{l}\text { A blocking and regularization approach to high } \\
\text { dimensional realized covariance estimation }\end{array}$ \\
\hline 2009/19 & $\begin{array}{l}\text { Guenter W. Beck } \\
\text { Volker Wieland }\end{array}$ & $\begin{array}{l}\text { Money in Monetary Policy Design: Monetary } \\
\text { Cross-Checking in the New-Keynesian Model }\end{array}$ \\
\hline $2009 / 18$ & $\begin{array}{l}\text { Wolfgang Karl Härdle } \\
\text { Nikolaus Hautsch } \\
\text { Andrija Mihoci }\end{array}$ & $\begin{array}{l}\text { Modelling and Forecasting Liquidity Supply } \\
\text { Using Semiparametric Factor Dynamics }\end{array}$ \\
\hline $2009 / 17$ & $\begin{array}{l}\text { John F. Cogan } \\
\text { Tobias Cwik } \\
\text { John B. Taylor } \\
\text { Volker Wieland }\end{array}$ & $\begin{array}{l}\text { New Keynesian versus Old Keynesian } \\
\text { Government Spending Multipliers }\end{array}$ \\
\hline $2009 / 16$ & Christopher D. Carroll & $\begin{array}{l}\text { Precautionary Saving and the Marginal } \\
\text { Propensity to Consume Out of Permanent } \\
\text { Income }\end{array}$ \\
\hline
\end{tabular}

2009/15 Christopher D. Carroll Olivier Jeanne

A Tractable Model of Precautionary Reserves, Net Foreign Assets, or Sovereign Wealth Funds

2009/14 Christopher D. Carroll Patrick Toche

A Tractable Model of Buffer Stock Saving

2009/13 Jan Pieter Krahnen Günter Franke

Instabile Finanzmärkte

2009/12 Christopher D. Caroll Jiri Slacalek

The American Consumer: Reforming, Or Just Resting?

Copies of working papers can be downloaded at http://www.ifk-cfs.de 